\title{
Link between Chronic Pesticides Exposure and Reproductive Problems in Male Farmers
}

\author{
Ghulam Nabi (Corresponding author) \\ M. Phil Scholar. Animal sciences Department,: Reproductive neuro-endocrinology Lab \\ Quaid-i-Azam University, (Islamabad) Pakistan
}

Tel: 92-345-811-2741Ｅ-mail: ghulamnabiqau@ gmail.com

Muhammad Amin

M. Phil Scholar, Department of Zoology, University of Karachi, Pakistan

Tel: 92-315-902-0833Ｅ-mail: aminmuhammad013@yahoo.com

Tabinda Rauf

M.Phil scholar, Department of Zoology, University of SBBU

Sheringal, Dir, Khyber Pakhtunkhwa, Pakistan

E-mail: tabindaraoof@gmail.com

Khwaja Muhammad Khan

B.sc (hon), Department of agriculture, Hazara University Haripur, Pakistan

Tel: 92-346-344-0311Ｅ-mail: kmk.dir@gmail.com

Ayaz Ali khan

Assistant Professor, Department of Biotechnology, University of Malakand

Chakdara, Dir Lower, Khyber pakhtunkhwa, Pakistan

Tel: 92-345-5886-0677Ｅ-mail: lalatejan@gmail.com

Received: April 24, 2014 Accepted: May 4, 2014

doi:10.5296/jbls.v5i2.5501 URL: http://dx.doi.org/10.5296/jbls.v5i2.5501 


\section{Abstract}

The demand for potent and new pesticides increases day by day because of pest resistant and more food production. The objective of this study was to find out the effects of chronic pesticides exposure on the reproductive health of poor and reckless farmers. A $5 \mathrm{~mL}$ blood was drawn from 80 men (40 farmers, 40 controls) and was analyze for serum total testosterone using Biocheck (USA) kit. A detail questionnaire was designed about socio-demographic, occupational activities and clinical characteristics.In farmer group the Mean \pm SEM of total serum testosterone was $546 \pm 10 \mathrm{ng} / \mathrm{dl}$ and in control was $664 \pm 17 \mathrm{ng} / \mathrm{dl}$. Total serum testosterone was significantly lowered $(P<0.0001)$ in farmers at $95 \%$ confidence interval as compared to control group. Reproductive health problems like infertility, erectile dysfunction, ejaculatory problems, decreased libido, absent morning and nocturnal erection and general health problems like asthma, rheumatoid arthritis, hypertension, Parkinson and diabetes mellitus were more common in farmers.

Pesticides negatively affect the physiology of endocrine system. It reduces the serum total testosterone concentration in farmers significantly. This low testosterone produces negative effects on the reproductive as well as general health.

Keywords: Libido, Infertility, Nocturnal.

\section{Introduction}

In today's world pesticides are one of the most important contaminant actively involved in environmental contamination. These chemicals are toxic to vectors of diseases and pest. Pesticides are marketed as herbicides, insecticides and fungicides. The demands for new and potent pesticides are increasing day by day because of pest resistance and more food production to fulfill the need of world growing populations. Only in European Union 140,000 tons of pesticides are used annually for agriculture purpose, such sort of extensive application raised the questions about hazards of pesticides to human health, including reproductive. On one side pesticides helped the human by controlling infectious diseases and increasing the yield of agriculture products. But on the other hand their extensive long term use can harm the health. Pesticides can disturb the physiology of reproductive, endocrine, renal, cardiovascular, respiratory, nervous and immune system causing Alzheimer, multiple sclerosis, diabetes, Parkinson, renal and cardiovascular problems (Abdollahiet al., 2004;Ramazzini, 2009; De Souza et al., 2011;Mostafalou and Abdollahi, 2012).

Most of the pesticides cause reproductive toxicities by interfering with the physiology of endocrine system (Figa-Talamanca et al., 2001; Cocco, 2002; Tiemann, 2008). Pesticides like,endosulfans, dieldrin, DDT and aldrin, the herbicides atrazine and the fungicide vinclozoline are considered as endocrine disruptor chemicals (PAN, 2009). Both male and female reproductive systems are negatively affected by pesticides exposure (Kumar, 2004; Shojaei and Abdollahi, 2012). Chronic pesticides exposure can causes decreased fertility in both sexes, high rate of miscarriage, altered sex ratio and has also antiandrogenic effects (Frazier, 2007).Pesticides exposure causes hormonal imbalance that eventually leads to infertility and sterility. Pesticides like, carbamates, pyrethroids, organophosphatases, Thio-and 
dithiocarbamates, chlorphenoxy acids and chlormethylphosporic acids reduces testosterone concentrations in male after acute exposure during exposure season (Evamarieet al., 1999).A pesticide that changes the physiology of endocrine system by acting as hormone agonists/antagonists or changing endogenous steroidal hormonal level may negatively affect the developmental, biochemical and behavioral functions that are very important for reproductive success (Gerald et al., 1997). Pesticides are endocrine disrupting chemicals (EDCs) that interfere with the synthesis, transport, metabolism and elimination of hormone there by, changing the concentration of natural hormone (Gore, 2010).Up to now a totals of 101 pesticides have listed to be endocrine disruptors (EDs) by the pesticides action network UK (PAN, 2009).

In Pakistan especially in district Dir (lower) the awareness about pesticides hazardous effects is lacking in farmers either due to illiteracy or poverty. These farmers never use masks, gloves, eye glasses and other protective coverings during fumigations. They even never wash their hands after fumigationand take their breakfast or meal in their fields. During fumigation, all the clothes and body of farmers are washed by pesticides. They are also addicted to snuff which during fumigation are contaminated by pesticides. For the sake of high yields with low efforts they uses excessive and multiple pesticides. These farmers are exposed to pesticides from generation to generation. The present study is design to analyze the ill effects of pesticides on the male reproductive health of farmers.

\section{Material and methods}

\subsection{Pesticides Used in Study Population}

Most commonly used pesticides are Mancozeb, cymoxanil, metalaxyl, cypermethrin, tebuconazole, nitonpiram, hexythiazox,chlorothalonil, metiram, pyraclostrobin, dimethomorph, levofenoron, pyrimethanil, imidacloprid, thiophanate methyl, bromoxynil, MCPA, pendimethaline, nicosulfuron, atrazine and endosulfon (now banned).

\subsection{Inform Consent}

Before starting the study a written informed consent was signed by each participant.

\subsection{Study Population}

We selected the agriculture community of village Tazagram, district Dir lower, Khyber pakhtunkhwa, Pakistan for study. This area was selected because it is surrounded by agriculture fields whose main products include vegetables (tomatoes, onions, spinach, cauliflowers, cabbage, garlic, brinjals, ladyfingers)crops (maize, rice, wheat, tobaccos) as well as fruits (oranges, grapes, apricots, pears). It is situated at 695 meters above sea level. The climate is temperate so, agricultural production is possible all year round. We selected 80 men randomly from the community. They were divided into two groups i.e. control and exposed. Each group contained 40 participants. The exposed group participants were farmers by profession while control group participants were engage in other professions. Their age ranges from 29 to 50 years and were divided into two age groups i.e. $29-40$ and 41-50 respectively. Each participant was interviewed directly regarding his socio-demographic characteristics, alcohol and smoking 
habit, occupational activities and clinical characteristics.

\subsection{Inclusion Criteria}

Farmers directly exposed to pesticides for at least 20 years.

\subsection{Exclusion Criteria}

No history of chronic illness, chemotherapy and radiotherapy.

\subsection{Blood Sampling}

Samples were collected during the heavy spraying season (March to July). $5 \mathrm{~mL}$ of the morning blood sample was collected from the antecubital vein of each participant by a phlebotomist aseptically. Immediately blood was transferred into Vacutainer tube containing no additives. At room temperature blood was allowed to clot and then centrifuged at $3200 \mathrm{rpm}$ for 15 minutes at $4 \mathrm{C}^{0}$. The resulting serum samples were then stored at $-20^{\circ} \mathrm{C}$ for later analysis.

\subsection{Assay}

For the measurement of serum total testosterone, testosterone enzyme immunoassay test kit, Bio-check USA was used according to the manufacturer protocol and procedures.

\subsection{Data Analysis}

Analysis of data was done by using Graph Pad Prism (www.graphpad.com), version 6.03 (Graph Pad Software Inc., San Diego, CA, USA). Student un-paired $t$ test was used for the comparison of serum total testosterone in both groups. The results were represented through Mean \pm SEM. A value of $p<0.05$ was considered statistically significant.

\section{Results}

\subsection{Direct Fumigation Effects}

The farmers did not use protective coverings like, masks, gloves, dresses etc. so are directly exposed to pesticides. The effects like, headache, nausea, dizziness, cough, blurring of vision, throat, skin, nose and eye irritation were common in farmers during and after fumigations.

\subsection{Selected Characteristics of the Study Population}

The characteristics of the study population are presented in Table 1

Table 1. Characteristics of the study population

\begin{tabular}{|l|c|l|l|l|l|l|l|}
\hline $\begin{array}{l}\text { Age } \\
\text { Group } \\
\text { (Years) }\end{array}$ & $\begin{array}{c}\text { Exposure } \\
\text { time to } \\
\text { pesticides } \\
\text { (years) }\end{array}$ & $\begin{array}{l}\text { Fumigation } \\
\text { frequency } \\
\text { (per week) }\end{array}$ & $\begin{array}{l}\text { Protective } \\
\text { clothing }\end{array}$ & $\begin{array}{l}\text { Hand } \\
\text { wash }\end{array}$ & $\begin{array}{l}\text { Addiction } \\
(\%)\end{array}$ & $\begin{array}{l}\text { General } \\
\text { health } \\
\text { problems }\end{array}$ & $\begin{array}{l}\text { Reproductive } \\
\text { health problems }\end{array}$ \\
\hline $\begin{array}{l}\text { Control } \\
29-40 \\
(\mathrm{n}=20)\end{array}$ & & & & yes & $\begin{array}{l}05 \text { snuff } \\
6 \text { cigarette }\end{array}$ & $01 \mathrm{DM}^{*}$ & absent \\
\hline
\end{tabular}




\begin{tabular}{|l|l|l|l|l|l|l|l|}
\hline $\begin{array}{l}41-50 \\
(\mathrm{n}=20)\end{array}$ & & & yes & $\begin{array}{l}11 \text { snuff } \\
6 \text { cigarette }\end{array}$ & $02 \mathrm{HT}^{*}$ & absent \\
\hline $\begin{array}{l}\text { Farmer } \\
29-40 \\
(\mathrm{n}=20)\end{array}$ & $\geq 20$ yrs. & $\geq 7 /$ week & absent & no & $\begin{array}{l}8 \text { snuff } \\
9 \text { cigarette }\end{array}$ & $\begin{array}{l}04 \mathrm{HT} \\
02 \mathrm{~A}^{*} \\
01 \mathrm{RA}^{*}\end{array}$ & $\begin{array}{l}02 \text { infertility } \\
04 \mathrm{DL}^{*} \\
03\end{array}$ \\
\hline $\begin{array}{l}41-50 \\
(\mathrm{n}=20)\end{array}$ & $\geq 20$ yrs. & $\geq 7 /$ week & absent & no & $\begin{array}{l}13 \text { snuff } \\
0 \text { cigarette }\end{array}$ & $\begin{array}{l}06 \mathrm{HT} \\
03 \mathrm{DM}\end{array}$ & $\begin{array}{l}02 \text { infertility } \\
04 \mathrm{DL} \\
02 \mathrm{PP}\end{array}$ \\
\hline
\end{tabular}

$\mathrm{DL}^{*}=$ Decreased Libido, $\mathrm{EP}^{*}=$ Erection Problems, $\mathrm{AMN}^{*}=$ Absent Morning and Nocturnal erection.

$\mathrm{DM}^{*}=$ Diabetes Mellitus, $\mathrm{HT}^{*}=$ Hypertension, $\mathrm{A}^{*}=$ Asthma, $\mathrm{RA}^{*}=$ Rheumatoid Arthritis, $\mathrm{P}^{*}=$ Parkinson,

\subsection{Analysis of total serum testosterone concentration in study population}

Total serum testosterone concentrations in both groups are summarized in Table 2. A significant reduction $(P<0.0001)$ in total serum testosterone concentration was found in farmers as compared to control group at $95 \%$ confidence interval.

Table 2. Total serum testosterone concentration in study population

\begin{tabular}{|l|l|l|l|l|}
\hline Parameters & $\begin{array}{l}\text { Control } \\
\text { Mean } \pm \text { SEM }\end{array}$ & $\begin{array}{l}\text { Farmer } \\
\text { Mean } \pm \text { SEM }\end{array}$ & $95 \%$ C.I* & $P$ value \\
\hline Total serum testosterone concentration & $664 \pm 17(\mathrm{ng} / \mathrm{dl})$ & $546 \pm 10(\mathrm{ng} / \mathrm{dl})$ & -158 to -78.61 & $<0.0001$ \\
\hline
\end{tabular}

$\mathrm{CI}^{*}=$ Confidence Interval

\section{Discussion}

Our main finding in this study were low serum total testosterone, reproductive and general health problems, that were more pronounce in farmers as compared to control group. In this community the most common symptoms related to pesticides reported were nausea, headache, dizziness, blurring of vision, throat, skin, nose and eye irritations that were in agreements with other reports link with direct exposure to Organophosphates (OP) and carbamates (CB) pesticides (Catanoet al., 2008).Total serum testosterone and estradiol level decreases in peoples exposed to OP (Padungtodet al., 1998; Straubeet al., 1999). Experimentally this is confirmed that, OP exposure alters the metabolism of testosterone and estradiol (Butler and Murray 1993; Murray and Butler 1995) thus supporting our results.OPaffects the reproductive functions primarily via decreasing brain acetylcholinesterase (AChE) activity and secondarily via gonads. This decrease in AChE leads to increase the concentration of acetylcholine, gamma-aminobutyric acid (GABA), epinephrine, norepinephrine, 5-hydoxytryptamine and dopamine concentration (Glissonet al., 1974; Gupta et al., 1984). Increased level of GABA then inhibit the release of gonadotropin releasing hormone $(\mathrm{GnRH})$ in the median eminence, which is responsible for the release of luteinizing hormone (LH) and follicle stimulating 
hormone (FSH) from the anterior pituitary. These LH and FSH are then involved in steriodogenesis and gametogenesis (Mitsushimaet al., 1994; Terasawa and Fernandez, 2001). Like nicotine and cocaine, pesticides increases dopamine concentration that negatively regulate GnRH secretion suppressing the reproductive functions( Kuharet al., 1991; Corrigallet al., 1992; Murphy et al., 1998; Di Chiara, 2000; Watkins et al., 2000). OP and carbamates alter pituitary adrenal axes (Clement 1985; Kokkaet al., 1987). Acephate andmetamidophos stimulate the secretion of hypothalamic corticotropin-releasing hormone, which in turn stimulate adrenocorticotropic hormone (ACTH) and so cortisol(Spassovaet al., 2000). Receptor of cortisol are located on GnRH neurons, RFRP-3(mammalian ortholog of GnIH) and on gonadotrops. High cortisol level inhibits the secretion of GnRH and so LH and testosterone while positively regulate RFRP-3 secretion, thus suppressing reproductive system (Kirby et al., 2009). OP and CB affect the pituitary-thyroidal axes (Clement, 1985)reducing the level of serum fT4 (free thyroxin) in farmers (Khan et al., 2013) by increasing T4 metabolism through induction of of hepatic UDP-glucuronosyltranferase enzymes (Hill et al., 1989)and to displacement of T4 from plasma binding-proteins, altering hepatic androgen metabolism (Van et al., 1991). The pesticides like imidacloprid (IMI) and acetamiprid (ACE) bind to insect nicotinic acetylcholine receptor in central nervous systems and kill them (Tomizawa and Casida, 2005). But in vivo studies have found that neonicotinoid pesticides including IMI and ACE affect the reproductive organs of mammals causing retardation of testicular development, damage to spermatogenesis, decrease in sperm quality and change of ovary morphology (Kapooret al., 2010; Kapooret al., 2011; Balet al., 2012 a ; Balet al., 2012 ). OP exposure can result paternal fertility problems. OPisgenotoxic to animal sperm because it is a very potent phosphorylating agent. It binds to DNA and protamines, altering the chromatin structure that results DNA to become more susceptible to induced denaturation in situ (Evensonet al., 2002; Sergerieet al., 2005;Pina-Guzman et al., 2005;Boe-Hansen et al., 2006;). In Chinese pesticides factory workers the effects of OP exposure on their reproductive system was done. It was found that OP exposure increases LH and FSH but decreases serum total testosterone (Padungtodet al.,1998).In adult men OP and CB metabolites reduces the serum level of LH and total testosterone (Meeker et al., 2006).In Djutitsa (West Cameroon) a significant reduction in serum total testosterone and androstenedionewere found in farmers exposed to agro pesticides (Manfoet al., 2010). A lot of wildlife species have been effected by endocrine disrupting chemicals(EDCs) showing alteration in penis/gonopodium development, decreased testosterone level, alters spermatogenesis, impaired reproduction, reduce hatchability and/ or viability of offspring, aberrant sexual behavior and affect sex determination, differentiation of the gonads and timing of sexual maturation(Oberdörster and Cheek, 2001; IPCS, 2002; Stoker et al., 2003;Joblinget al., 2006; Milneset al., 2006; Crain et al., 2007; Orlando and Guillette, 2007;Guillette and Edwards, 2008;Stoker et al.,2008). Exposure toendosulfan (END) and atrazine (ATZ) during the embryonic life of Caiman latirostisaltered histoarchitecture of the testis as well as the balance between proliferation and apoptosis of hatchlings' testicular cells. In adult male exposed to END, a decreased testosterone level was observed (Florenciaet al., 2009). Impaired testicular functions were also suggested for factory workers exposed to chlordecone (Anderson et al., 1976). Delayed spermatogenesis, decreased sperm counts, altered sperm motility and a higher incidence of intersex were observed in fishes exposed to 


\section{Al Macrothink}

Journal of Biology and Life Science ISSN 2157-6076 2014, Vol. 5, No. 2

END (Joblinget al., 2002; Aravindakshanet al., 2004; de Montgolfier et al., 2008). Some studies have found high testosterone level (Sarkaret al., 2000) or no significant change in the testosterone level (Rogelio et al., 2005) of model animals as well as human exposed to pesticides. This may be due to the agrochemicals use, severity and/or length of exposure, agricultural practices and protection equipment pattern of use (Rogelio et al., 2005).

\section{Conclusion}

In summary pesticides exposure negatively affects the endocrine system directly or indirectly, resulting into serious consequences. In district Dir there is a need to educate the farmers about the appropriate use of pesticides, implement a formal worker protection program for agricultural workers and preventive health monitoring for early detection of pesticide exposure.

\section{References}

Anderson, JJH. Cohn, WJ. Guzelian, P. Taylor, JR. Griffith, FD. Blanke, FD. Dos Santos, \& JG. Blackard G. (1976). Effects of kepone associated toxicity on testicular functions. Abstr.58th Ann. Meet.Endocrine Society, San Francisco, CA.

Abdollahi, M. Ranjbar, A. Shadnia, S. Nikfar, \& S. Rezaie, A. (2004). Pesticides and oxidative stress: a review. Medical Science Monitor, 10, 141-147.

Aravindakshan, J. Paquet, V. Gregory, M. Dufresne, J. Fournier, M. Marcogliese, DJ., \& Cyr, DG. (2004). Consequences of xenoestrogen exposure on male reproductive function in spottail shiners (Notropishudsonius).Toxicological Sciences, $\quad 78, \quad 156-165$. http://dx.doi.org/10.1093/toxsci/kfh042

Butler, AM. Murray, M. (1993). Inhibition and inactivation of constitutive cytochrome P450 in rat liver by parathion.Molecular Pharmacology, 43, 902-908.

Boe-Hansen, GB, Fedder, J. Ersbøll, AK., \& Christensen, P. (2006). The sperm chromatin structure assay as a diagnostic tool in the human fertility clinic. Human Reproduction. 21, 1576-82. http://dx.doi.org/10.1093/humrep/de1019

Bal, R. Naziroglu, M. Turk, G. Yilmaz, \& O. Kuloglu, T. (2012)a. Insecticide imidacloprid induces morphological and DNA damage through oxidative toxicity on the reproductive organs of developing male rats. Cell Biochemistry and Function. 30, 492-499.

Bal, R. Turk, G. Tuzcu, M. Yilmaz, O., \& Kuloglu, T. (2012)b. Assessment of imidacloprid toxicity on reproductive organ system of adult male rats. Journal of Environmental Sciences and Health B. 47, 434-444. http://dx.doi.org/10.1080/03601234.2012.663311

Clement, JG. (1985). Hormonal consequences of organophosphate poisoning.Fundamental Applied Toxicology. 5, 67-77. http://dx.doi.org/10.1016/0272-0590(85)90115-0

Corrigall, WA. Franklin, KBI. Coen, KM. Clarke, PBS. (1992). The mesolimbic dopamine system is implicated in the reinforcing effects of nicotine. Psychopharmacology. 107, 285-289. http://dx.doi.org/10.1007/BF02245149 
Cocco, P. (2002). On the rumors about the silent spring. Review of the scientific evidence linking occupational and environmental pesticide exposure to endocrine disruption health $\begin{array}{lllll}\text { effects. Cadernos } & \text { de } & \text { SaudePublica. } & 18, & 379-402 .\end{array}$ http://dx.doi.org/10.1590/S0102-311X2002000200003

Crain, A. Eriksen, M. Iguchi, T. Jobling, S. Laufer, H. LeBlanc, GA., \& Guillette, LJ. (2007). An ecological assessment of bisphenol-A: evidence from comparative biology. Reproductive Toxicology. 24, 225-239. http://dx.doi.org/10.1016/j.reprotox.2007.05.008

Cataño, HC. Carranza, E.Huamaní, C., \& Hernández, AF. (2008). Plasma cholinesterase levels and health symptoms in Peruvian farm workers exposed to organophosphate pesticides.Archives of Environmental Contamination and Toxicology. 55, 153-9. http://dx.doi.org/10.1007/s00244-007-9095-0

Di Chiara, G. (2000). Role of dopamine in the behavioural actions of nicotine related to addiction. European Journal of Pharmacology. 393, 295-314. http://dx.doi.org/10.1016/S0014-2999(00)00122-9

de Montgolfier, B. Fournier, M.Audet, C.Marcogliese, DJ., \& Cyr, DG. (2008). Influence of municipal effluents on the expression of connexins in the brook trout (Salvelinusfontinalis) testis.Aquatic Toxicology. 86, 38-48. http://dx.doi.org/10.1016/j.aquatox.2007.09.013

De Souza, A. Medeiros, AR. De Souza, AC. Wink, M.Siqueira, IR. Ferreira, MB. Fernandes, L.Loayza, MP., \& Torres, IL. (2011). Evaluation of the impact of exposure to pesticides on the health of the rural population: Vale do Taquari, State of Rio Grande do Sul (Brazil). CienSaude Colet, 16, 3519-3528.

Evamarie, S. Wolfgang, S.Egon, K. Matthias, B.Margitta, JM., \& Hans, JR. (1999). Disruption of male sex hormones with regard to pesticides: pathophysiological and regulatory aspects. Toxicology Letters. 107, 225-231. http://dx.doi.org/10.1016/S0378-4274(99)00051-X

Evenson, DP. Larson, KL., \& Jost, LK. (2002). Sperm Chromatin Structure Assay: its clinical use for detecting sperm DNA fragmentation in male infertility and comparisons with other techniques. Journal ofAndrology. 23, 25-43.

Figa-Talamanca, I.Traina, ME., \& Urbani, E. (2001). Occupational exposures to metals, solvents and pesticides: recent evidence on male reproductive effects and biological markers. Occupational Medicine. 51, 174-188. http://dx.doi.org/10.1093/occmed/51.3.174

Frazier, LM. (2007). Reproductive disorders associated with pesticide exposure. Journal ofAgromedicine. 12, 27-37.

Florencia, R. Marianela, G. Marcelo, AZ. Cora, S., \& Milena, D. (2009). Prenatal exposure to pesticides disrupts testicular histoarchitecture and alters testosterone levels in male Caiman latirostris. General and Comparative Endocrinology. 162, 286-292. http://dx.doi.org/10.1016/j.ygcen.2009.03.032

Glisson, SN. Karczmar, AG., \& Barnes, L. (1974). Effects of diisopropylphosphorofluoridate on acetylcholine, cholinesterase and catecholamines of several parts of rabbit 
brain.Neuropharmacology. 13, 623-631. http://dx.doi.org/10.1016/0028-3908(74)90052-5

Gupta, M.Bagchi, GK. Gupta, SD.Sasmal, D.Chatterjee, T., \& Dey, SN. (1984). Changes of acetylcholine, catecholamines and amino acid in mice brain following treatment with $\begin{array}{llll}\text { Nuvacron } \quad \text { and } & \text { Furadan.Toxicology. } & \text { 171-175. }\end{array}$ http://dx.doi.org/10.1016/0300-483X(84)90127-6

Gerald, AL. Lisa, JB., \& Vickie, SW. (1997)Pesticides: multiple mechanisms of demasculinization. Molecular and Cellular Endocrinology. 125, 1-5.

Guillette, LJ., \& Edwards, TM. (2008). Environmental influences on fertility: can we learn lessons from studies of wildlife? Fertility and Sterility. 89, 21-24. http://dx.doi.org/10.1016/j.fertnstert.2007.12.019

Gore, AC. (2010). Neuroendocrine targets of endocrine disruptors. Hormones. 9, 16-27. http://dx.doi.org/10.14310/horm.2002.1249

Hill, RN.Erdreich, LS.Paynter, OE. Roberts, PA. Rosenthal, SL., \& Wilkinson, CF. (1989). Thyroid follicular cell carcinogenesis.Fundamental and Applied Toxicology. 12, 629-697. http://dx.doi.org/10.1016/0272-0590(89)90001-8

IPCS. (2002). Global Assessment of the State-of-the-Science of Endocrine Disruptors.International Program of Chemical Safety, World Health Organization, Geneva, Switzerland.

Jobling, S. Beresford, N. Nolan, M. Rodgers-Gray, T. Brighty, GC.Sumpter, JP., \& Tyler, CR. (2002). Altered sexual maturation and gamete production in wild roach (Rutilusrutilus) living in rivers that receive treated sewage effluents. Biology of Reproduction. 66, 272-281. http://dx.doi.org/10.1095/biolreprod66.2.272

Jobling, S. Williams, R. Johnson, A. Taylor, A. Gross-Sorokin, M. Nolan, M. Tyler, CR. Van, AR. Santos, E., \& Brighty, G. (2006). Predicted exposures to steroid estrogens in U.K. Rivers correlate with widespread sexual disruption in wild fish populations. Environmental Health Perspectives. 114, 32-39. http://dx.doi.org/10.1289/ehp.8050

Kokka, N. Clemons, GK., \& Lomax, P. (1987). Relationship between the temperature and endocrine changes induced by cholinesterase inhibitors.Pharmacology. 34, 74-79. http://dx.doi.org/10.1159/000138255

Kuhar, MJ. Ritz, MC., \& Boja, JW. (1991). The dopamine hypothesis of the reinforcing properties of cocaine. Trends in Neurosciences.14, 299-302. http://dx.doi.org/10.1016/0166-2236(91)90141-G

Kumar, S. (2004). Occupational exposure associated with reproductive dysfunction. Journal of Occupational Health. 46, 1-19. http://dx.doi.org/10.1539/joh.46.1

Kirby, ED. Geraghty, AC. Ubuka, T. Bentley, GE., \& Kaufer, D. (2009). Stress increases putative gonadotropin inhibitory hormone and decreases luteinizing hormone in male rats. Proceedings of the National Academy of Sciences USA. 106, 11324-11329. 
Kapoor, U. Srivastava, MK. Bhardwaj, S. Srivastava, LP. (2010). Effect of imidacloprid on antioxidant enzymes and lipid peroxidation in female rats to derive its. No Observed Effect Level (NOEL). Journal of Toxicological Sciences. 35, 577-581. http://dx.doi.org/10.2131/jts.35.577

Kapoor, U. Srivastava, MK. Srivastava, LP. (2011). Toxicological impact of technical imidacloprid on ovarian morphology, hormones and antioxidant enzymes in female rats.Food Chemical Toxicology. 49, 3086-3089. http://dx.doi.org/10.1016/j.fct.2011.09.009

Khan, DA. Ahad, K. Ansari, WM., \& Khan, H. (2013). Pesticide exposure and endocrine dysfunction in the cotton crop agricultural workers of southern Punjab, Pakistan. Asia Pacific Journal of Public Health. 25,181-91. http://dx.doi.org/10.1177/1010539511417422

Mitsushima, D. Hei, DL., \& Terasawa, E. (1994). GABA is an inhibitory neurotransmitter restricting the release of luteinizing hormone-releasing hormone before the onset of puberty. Proceedings of the National Academy of Sciences USA. 91, 395-399.

Murray, M., \& Butler, AM. (1995). Identification of a reversible component in the in vitro inhibition of rat hepatic cytocrome P450 2B1 by parathion.Journal of Pharmacology and Experimental Therapeutics. 272, 639-644.

Murphy, LL. Munoz, RM. Adrian, BA., \& Villanu, MA. (1998). Function of cannabinoid receptors in the neuroendocrine regulation of hormone secretion.Neurobiology of Diseases. 5, 432-446. http://dx.doi.org/10.1006/nbdi.1998.0224

Meeker, J. Ryan, L. Barr, D., \& Hauser, R. (2006).Exposure to nonpersistent insecticides and $\begin{array}{lllll}\text { male } \quad \text { reproductive } & \text { hormones. } & \text { Epidemiology. }\end{array}$ http://dx.doi.org/10.1097/01.ede.0000190602.14691.70

Milnes, MR. Bermudez, DS. Bryan, TA. Edwards, TM. Gunderson, MP. Larkin, IL. Moore, BC., \& Guillette, JR. (2006). Contaminant-induced feminization and demasculinization of nonmammalian vertebrate males in aquatic environments.Environmental Resistance. 100, 3-17. http://dx.doi.org/10.1016/j.envres.2005.04.002

Manfo, FP. Moundipa, PF., \& Déchaud, H. (2010). Effect of agropesticides use on male reproductive function: a study on farmers in Djutitsa (Cameroon). Environmental Toxicology.Epub ahead of print.

Mostafalou, S., \& Abdollahi, M. (2012)a. Concerns of environmental persistence of pesticides and human chronic diseases. Clinical and Experimental Pharmacology. 2, 1000-1108.

Oberdörster, E., \& Cheek, AO. (2001). Gender benders at the beach: endocrine disruption in marine and estuarine organisms. Environmental Toxicology Chemistry. 20, 23-36. http://dx.doi.org/10.1002/etc.5620200103

Orlando, EF., \& Guillette, JR. (2007). Sexual dimorphic responses in wildlife exposed to endocrine disrupting chemicals. Environmental Resistance. 104, 163-173. http://dx.doi.org/10.1016/j.envres.2006.06.002 
Padungtod, C. Lasley, BL.Christiani, DC. Ryan, LM., \& Xu, X. (1998).Reproductive hormone profile among pesticide factory workers.Journal of Occupational and Environmental Medicine. 40, 1038-1047. http://dx.doi.org/10.1097/00043764-199812000-00002

Piña-Guzman, B. Solís-Heredia, MJ., \& Quintanilla-Vega, B. (2005). Diazinon alters sperm chromatin structure in mice by phosphorylating nuclear protamines. Toxicology Applied Pharmacology.202, 189-98. http://dx.doi.org/10.1016/j.taap.2004.06.028

PAN. (2009). List of Lists: A Catalogue of Lists of Pesticides Identifying Those Associated with Particularly Harmful Health or Environmental Impacts. P. A. Network.

Rogelio, R. Guadalupe, OG. Javier, MM., \& Victor, BA. (2005). Pesticide Exposure Alters Follicle-Stimulating Hormone Levels in Mexican Agricultural Workers. Environmental Health Perspectives. 113, 1160-1163. http://dx.doi.org/10.1289/ehp.7374

Ramazzini, C. (2009). Collegium Ramazzini statement on the control of pesticides in the European Union: a call for action to protect human health. American Journal of Industrial Medicine. 52, 176-177. http://dx.doi.org/10.1002/ajim.20654

Straube, E.Straube, W. Kruger, E.Bradatsch, M. Jacob-Meisel, M., \& Rose, HJ. (1999). Disruption of male sex hormone with regard to pesticides: pathophysiological and regulatory aspects. Toxicology Letter. 107, 225-231. http://dx.doi.org/10.1016/S0378-4274(99)00051-X

Sarkar, R. Mohanakumar, KP., \& Chowdhury, M. (2000).Effects of an organophosphate pesticide, quinalphos, on the hypothalamopituitary- gonadal axis in adult male rats.Journal of Reproduction and Fertility. 118, 29-38.

Spassova, D. White, T., \& Singh, AK. (2000). Acute effects of acephate and metamidophos on acetylcholinesterase activity, endocrine system and amino acid concentration in rats.Comparative Biochemistry and Physiology part C Toxicology and Pharmacology. 126, 79-89.

Stoker, C. Rey, F. Rodriguez, HA. Ramos, JG. Sirosky, P.Larriera, A. Luque, EH., \& Muñoz-de-Toro, M. (2003). Sex reversal effects on Caiman latirostris exposed to environmentally relevant doses of the xenoestrogenbisphenol.American General and Comparative Endocrinology. 287-296. http://dx.doi.org/10.1016/S0016-6480(03)00199-0

Sergerie, M. Laforest, G. Bujan, L. Bissonnette, F., \& Bleau, G. (2005). Sperm DNA fragmentation: threshold value in male fertility. Human Reproduction. 20, 3446-51. http://dx.doi.org/10.1093/humrep/dei231

Stoker, C. Beldoménico, PM. Bosquiazzo, VL. Zayas, MA. Rey, F. Rodríguez, H. Muñoz-de-Toro, M., \& Luque, EH. (2008). Developmental exposure to endocrine disruptor chemicals alters follicular dynamics and steroid levels in Caiman latirostris. General and Comparative Endocrinology. 156, 603-612. http://dx.doi.org/10.1016/j.ygcen.2008.02.011

Shojaei, SH., \& Abdollahi, M. (2012). Is there a link between human infertilities and exposure to pesticides? Internal Journal of Pharmacology. 8, 708-710. 


\section{Macrothink}

Terasawa, E., \& Fernandez, DL. (2001). Neurobiological mechanisms of the onset of puberty in primates.Endocrine Review. 22, 111-151.

Tomizawa, M.Casida, JE. (2005). Neonicotinoid insecticide toxicology: mechanisms of selective action. Annual Review of Pharmacology and Toxicology. 45, 247-268. http://dx.doi.org/10.1146/annurev.pharmtox.45.120403.095930

Tiemann, U. (2008). In vivo and in vitro effects of the organochlorine pesticides DDT, TCPM, methoxychlor, and lindane on the female reproductive tract of mammals: a review. Reproductive Toxicology. 25, 316-326. http://dx.doi.org/10.1016/j.reprotox.2008.03.002

Van den, BKJ. Van Raaij, JAGM. Bragt, PC., \& Notten, WRF. (1991). Interactions of halogenated industrial chemicals with transthyretin and effects on thyroid hormone levels in vivo.Archive of Toxicology. 65, 15-19.

Watkins, SS.Koob, GF., \& Markou, A. (2000). Neural mechanisms underlying nicotine addiction: acute positive reinforcement and withdrawal. Nicotine Tobacco Research. 2, 19-37. http://dx.doi.org/10.1080/14622200050011277

\section{Copyright Disclaimer}

Copyright for this article is retained by the author(s), with first publication rights granted to the journal.

This is an open-access article distributed under the terms and conditions of the Creative Commons Attribution license (http://creativecommons.org/licenses/by/3.0/). 